\title{
Time and commitment: the grammaticalization of uúch in Lakandon Maya
}

Tiempo y compromiso: la gramaticalización de uúch en maya lacandon

Temps et engagement : la grammaticalisation de uúch en maya lacandon

\section{Henrik Bergqvist}

\section{(2) OpenEdition}

\section{Journals}

Electronic version

URL: http://journals.openedition.org/jsa/15114

DOI: 10.4000/jsa.15114

ISSN: 1957-7842

Publisher

Société des américanistes

Electronic reference

Henrik Bergqvist, "Time and commitment: the grammaticalization of uúch in Lakandon Maya », Journal de la société des américanistes [Online], Maya times | 2017, Online since 31 December 2017, connection on 30 April 2019. URL : http://journals.openedition.org/jsa/15114 ; DOI : 10.4000/ jsa. 15114 


\title{
Time and commitment: the grammaticalization of uúch in Lakandon Maya
}

\author{
Henrik BERGQVIST*
}

The paper accounts for the grammaticalization of uúch, ('previously', 'long ago') from a one-place predicate in Yukatek Maya meaning 'to happen', to a cognate adverbial in Lakandon Maya denoting 'knowledge asymmetry'; a change from subjective 'time' to intersubjective 'knowledge'. The paper proposes an analysis of uúch and the contrasting kuúch/ka'ch as operators of second-order stance, using a Jakobsonian model for analyzing verbal categories forwarded by Paul Kockelman (2004) to operationalize the notion of stance, as visible in Q'eqchi' modals. Intersubjectification as a process of language change aligns with Kockelman's original suggestion that first-order stances may be embedded to produce second-order stances, i.e. "stance about stance". [Key words: Lakandon Maya, grammaticalization, intersubjectivity, shifters, event-type, commitment.]

Tiempo y compromiso: la gramaticalización de uúch en maya lacandon. El artículo da cuenta de la gramaticalización de uúch ("anteriormente, hace tiempo"), un morfema que pasó de ser, en maya yucateco, un predicado monario con el significado "suceder" a ser, en maya lacandón, un adverbio cognado que denota asimetría de saber, es decir sufrió un cambio del tiempo subjetivo al saber intersubjetivo. Se propone que uúch y su par contrastivo kuúch/ka'ch funcionan como operadores de posicionamiento (stance) de segundo orden. El análisis se basa en un modelo jakobsoniano aplicado a las categorías verbales que fue incrementado por Paul Kockelman (2004), a partir del estudio de los modales del maya q'eq'chi', para volver operatoria la noción de posicionamiento (stance). La intersubjetivización es un proceso de cambio lingüístico que se alinea con la sugestión original de Kockelman, según la cual los posicionamientos de primer orden pueden imbricarse para producir posicionamientos de segundo orden, es decir transformarse en "posicionamientos sobre posicionamientos" (stance about stance). [Palabras claves: maya lacandon, grammaticalisación, intersubjectividad, conmutadores (shifters), tipo de evento, compromiso.]

Temps et engagement: la grammaticalisation de uúch en maya lacandon. L'article rend compte de la grammaticalisation de uúch («autrefois, il y a longtemps»), un morphème correspondant, en maya yucatèque, a un prédicat à une place signifiant

* Stockholm University, Sweden [henrik.bergqvist1@gmail.com] 
«survenir» et devenu, en maya lacandon, un adverbe cognat qui dénote une asymétrie de savoir, c'est-à-dire qui a connu un passage du temps subjectif au savoir intersubjectif. L'article propose d'interpréter uúch et sa paire contrastive kuúch/ka 'ch comme des opérateurs de positionnement (stance) de second ordre, une analyse qui se fonde sur le modèle jakobsonien appliqué aux catégories verbales, et augmentée par Paul Kockelman (2004), à partir d'une étude des modaux du maya q'eqchi', pour rendre opératoire la notion de positionnement (stance). L'intersubjectivisation est un processus de changement linguistique qui s'inscrit dans la proposition originale de Kockelman, selon laquelle les positionnements de premier ordre peuvent être imbriquées pour produire des positionnements de second ordre, à savoir des positionnements sur des positionnements (stance about stance). [Mots-clés: maya lacandon, grammaticalisation, intersubjectivité, embrayeurs (shifters), type d'évènement, engagement.]

\section{Introduction}

The paper traces the grammaticalization of uuch', ('previously', 'long ago') from a one-place predicate in Yukatek Maya to a cognate adverbial in Lakandon Maya. The change in function and meaning that has occurred in uuch is from subjective to intersubjective meaning, i.e. subjective 'time' to intersubjective 'knowledge'. This process can be viewed as a grammatical mapping onto the forms kuúch/ka'ch ('previously', 'a while ago'), which are cognate to forms found in Colonial and Modern Yukatek². Semantically, the contrast between uúch and $k u u c h / k a ' c h$ is between states and events that are exclusive knowledge to the speaker (uuch) and those that are assumed to be shared knowledge between the speaker and the addressee (kuúch/ka'ch). The basic contrast between uúch as a marker of knowledge asymmetry and $\mathrm{ka}^{\prime} \mathrm{ch}$ as a marker of knowledge symmetry can be seen in Examples (1) and (2), which are from a procedural narrative about making traditional Lakandon baskets:

(1)
$a-u u ́ c h-i k$
ma' inw-eer u-chuhn-a'
DET-before.EXCL-ADV.FOC NEG1 1S.A-know 3s.A-begin-MPASS
'Before, I didn't know how it was begun (tying a basket)'

(2) $a-k \boldsymbol{a}$ 'ch-ik

$$
\text { ma' inw-eer u-chu'un-u' }
$$

DET-before.INCL-ADV.FOC NEG1 1s.A-know 3s.A-begin-CPASS

'Before (as I have told you), I didn't know how one begun.' (HB041025_ChN_1)

In (1), the speaker informs the addressee (i.e. the author of the present paper) of her previous inability to start tying a basket. After having detailed how

1. The orthographic conventions used in this paper follow the Official Mayan Orthography (England and Elliot 1990).

2. kuúch/ka'ch are not suggested to have the same origin/status in Yukatek. They do have an identical function-meaning in Southern and Northern Lakandon, respectively. 
she eventually acquired this skill, she repeats essentially the same statement (2) assuming that the addressee has heard and remembers this, given his stated interest in learning about how the speaker ties baskets. uuch and $k a$ 'ch thus refers to the speaker's assumptions regarding the addressee's access to knowledge about an event/state that took place at some unspecified time in the past.

Following a discussion of these forms, the paper goes on to explore uúch and $\mathrm{kuu}$ ch/ka'ch as a form of epistemic marking, which may be accounted for using a Jakobsonian (Jakobson 1990 [1957]) model of (epistemic) stance forwarded by Kockelman $(2004,2010)$ in his analysis of epistemic modality in Q'eqchi'. Using this analytical model, uúch and kuúch/ka'ch are argued to signal a "secondary stance" where the speaker's commitment to an event includes assumptions regarding the addressee's commitment to the same event as either non-shared, or shared.

Lakandon Maya is spoken in the lowlands of southeastern Chiapas, Mexico by around 900 speakers. There is a relatively high degree of bilingualism for men but much less for women over 30 years of age. Lakandon is one of the four existing Yukatekan languages and is divided into two dialects: Southern Lakandon (SL), spoken in and around Lacanjá Chan Sayab and Northern Lakandon (NL), spoken in the area of Najá.

The Lakandon data presented in this paper was recorded and processed by the author between 2003 and 2007, first under the auspices of the Project for the Documentation of the Languages of Meso-America (PDLMA, http://www. albany.edu/pdlma), and later as a documentation of Lakandon Maya funded by the Endangered Languages Documentation Programme (ELDP, http:/www. hrelp.org; grant IGS0038). More recent research on these materials was funded by the Swedish Research Council (grant 2011-2274) and a post-doctoral grant from Åke Wiberg stiftelse. The author gratefully acknowledges this support.

Several genres are represented in the materials: conversation, traditional storytelling, personal narratives, and expository discourse, with a bias towards traditional storytelling and personal narratives. The collected language materials consist of some 30 hours of recorded speech (audio) of which about 15 hours have been transcribed and (partly) analyzed. About 3 hours of video was recorded. The materials are archived with the ELAR in London (http://elar.soas.ac.uk/).

\section{A note on grammaticalization}

Grammaticalization is a process of language change whereby content words become function words (e.g. Bybee et al. 1994). It is generally viewed as a cyclical and unidirectional process where different stages of grammaticalization are achieved. The unidirectional aspect of this process has been questioned (e.g. Campbell 2001), but it may in any case be regarded as a strong tendency. An example of grammaticalization is seen in the development of the 'future' 
will/'ll in English where will historically was a verb of volition (OE willan 'want', 'wish'), still visible in the somewhat archaic phrase, do what you will. It then acquired the status of an auxiliary with modal semantics ('intention') overlapping with tense meaning ('future'). In a later stage of development, will has been reduced to the clitic ' $l$, signaling only the tense meaning ('future').

Identified stages of this process are "semantic bleaching", "morphological reduction", "obligatorification", and "phonetic erosion". These sub-processes detail the loss of "concrete", lexical content in a morpheme that is becoming grammaticalized (semantic bleaching), the shortening and changed grammatical status of a morpheme in the grammar of the language (morphological reduction/obligatorification), and phonetic changes such as loss of stress (phonetic reduction). The resulting stages of grammaticalization are only visible in a full cycle and are not realized in every stage, nor with every morpheme subject to the grammaticalization process.

The notion of semantic bleaching is accompanied by the acquisition of a new function, which may be semantically less concrete than its previous lexical meaning, but often predictably related to the original meaning of a form. Cross-linguistic tendencies have been observed for the development of members of categories such as tense, aspect, mood/modality, and evidentiality. Perhaps the most salient of these tendencies is their origin in verbs, e.g. say may become grammaticalized to signal 'reported speech' and finish to express the aspectual 'perfect'.

Once a form has acquired a grammatical function, it can then develop new functions that are related to the original one. The cross-categorical grammaticalization of forms where e.g. aspect markers may become tense markers or evidentials is an example of this (e.g. Aksu-Koç and Slobin 1986 for Turkish $m i s$ ). Partly, this categorical transfer may be attributed to the fuzziness of categories in an analytical sense, but there are some cross-linguistic tendencies with regard to the way markers may acquire characteristics outside of their category membership resulting from the "conventionalization of implicatures" (Levinson 2000; see 'invited inferences', Traugott and Dasher 2002). Implied meaning thus becomes encoded in forms from conventional patterns of use, as visible in the development of perfects to become markers of past tense, or alternatively marking inference, depending on language specific circumstances.

A less well-explored grammaticalization process is observed by Traugott and Dasher (2002), namely the "intersubjectification" of modals and forms of social deixis (e.g. Fr. tu/vous). This process details how a 'subjective' expression (e.g. a modal marker) expands the speaker's point-of-view to also include the addressee's point-of-view. Traugott and Dasher discuss this development in the context of how epistemic markers acquire discourse functions and develop into discourse markers. The intersubjective meaning attributed to such forms is thus contingent on their function to relate aspects of the speech situation and the perspectives of the speech participants. 
The cross-categorical transfer of meaning and more specifically the intersubjectification of expressions of subjectivity have significance for the proposal forwarded here and in the sections below, I will detail how these processes can be seen in the grammaticalization of uúch in Lakandon.

\section{uúch in Yukatek}

In this and the following section, the grammaticalization of uúch is outlined by comparisons between all four spoken Yukatekan languages. In Yukatek, Itzaj and Mopan, cognates of uúch are attested as an intransitive verb meaning 'to happen' (Yukatek, Itzaj), or as a light verb in active constructions (Mopan, see Danziger 1996):

Yukatek

(3) b'a'x k-uy-uúch-ul

what INC-3S.A-happen-PLN.IV

'What's wrong?' (Bricker et al. 1998, p. 20 [my orthographic adjustments])

Itzaj

(4)
a-meyaj-oo' wa'ye'
what 3S.A-happen-PLN.IV DET-work-PL here
kil $\quad u$-k'och-ol 'agoostoj
when 3s.A-arrive-PLN.IV DET-month-NOM August
'What happens to the jobs when the month of August arrives?' (Hofling 2000, p. 648 [my orthographic adjustments])

Mopan

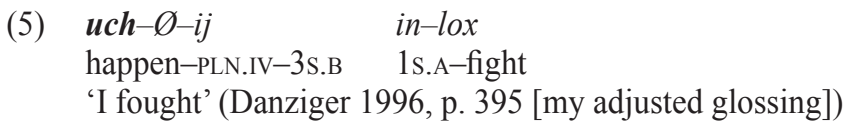

It is also possible to trace the grammaticalization of uuch from a verb to a temporal-modal (TM) marker in these languages (see Vapnarsky 1999 for Yukatek; Danziger 1996; Ulrich and Ulrich 1971 for Mopan; see Hofling 2000 for Itzaj). ${ }^{3}$ uúch as a TM-marker has the grammatical status of an auxiliary that is placed directly before the inflected verb. In this capacity, uúch is restricted to combine with the dependent status and cannot be inflected by proper verb morphology (see Bohnemeyer 1998; Vapnarsky 1999 for Yukatek). These differences are illustrated in examples (6) and (7) from Yukatek.

3. A slightly different development has occurred in Itzaj where $u c h a k$ has the meaning 'maybe'/'perhaps' (Hofling 2000, p. 365). 
Yukatek

(6) biin

FUT HYP happen-DEP.IV-3s.B again-TOP

'(One day) maybe it will happen again.' (Vapnarsky 1999, p. 113 [my translation and glossing/orthographic adjustments])

(7) le' iglèesya yàan te' Sàanta Krùus-o',

DET church exist LOC PL.N-TD.DIST

uúch men-t-ak-Ø

REM build-TRZ- DEP-3S.B

'The church in Santa Cruz, was built long ago.' (Vapnarsky 1999, p. 143 [my translation and glossing/orthographic adjustments])

In example (6), uúch is a fully inflected verb, whereas in (7) it modifies the verb me(e)n 'construct'. A further development of uúch in Yukatek is as an adverbial that is not restricted to occur before the verbal core.
Aa le'l-o
$k-i n-t s$ 'oon
uúch-e'
pixàan!
EXCL
DEM-TD.DIST
INC-1s-shoot
before-TD.ANA
soul
'Oh yes, I was shooting (at it) then, my soul!' (Vapnarsky 1999, p. 5 [tome 2; my translation and glossing/orthographic adjustments])

Descriptions of uuch in Yukatek usually focus on the verbal and TM variants. While uúch as an adverbial appears less frequently in Yukatek, the grammaticalization process has resulted in different circumstances for the adverbial uúch in Lakandon.

\section{uúch in Lakandon}

In Lakandon, a cognate to the Yukatek uuch is no longer present in the form of an intransitive verb. Given that uuch in the form of an intransitive verb is found in all other Yukatekan languages, this must be regarded as a special development in Lakandon. Only the TM-marker and the adverbial uuch are attested. Example (9) shows the TM-marker uuch and (10) features the adverbial:

\section{Lakandon}

\begin{tabular}{|c|c|c|c|c|}
\hline 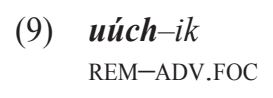 & $\begin{array}{l}s a j-a k \\
\text { scare-DEP.IV }\end{array}$ & $\begin{array}{l}m a \\
\text { NEG1 }\end{array}$ & $\begin{array}{l}\text { maák } \\
\text { person }\end{array}$ & $\begin{array}{l}k-u-n a ' k-a r \\
\text { INC-3s.A-go.up-PLN.IV }\end{array}$ \\
\hline ‘ich & uy-atooch & \multicolumn{3}{|c|}{$i k-n u u k i r-o$ ' } \\
\hline $\begin{array}{l}\text { LOC } \\
\text { 'Long ago, } \\
\text { (HB } 0409 \text { ? }\end{array}$ & $\begin{array}{l}\text { 3s.A-house } \\
\text { were afraid, n } \\
\text { ChK 4) }\end{array}$ & $\begin{array}{l}\text { 1PL.A } \\
\text { one en }\end{array}$ & $\begin{array}{l}\text { ncestors- } \\
\text { ed the } h\end{array}$ & $\begin{array}{l}\text { D.DIST } \\
\text { se of the ancest }\end{array}$ \\
\hline
\end{tabular}


(10)
uúch-ik
$k-u-t z i k b^{\prime} a-t-i k-\varnothing$
in-miim
before.EXCL-ADV.FOC
INC-3S.A-tell-TR-PLN-3S.B
1s.A-grandmother
'My grandmother used to tell (me)' (HB040922_1EChK_4)

While the placement and the actual form of uuch (with the adverbial focus marker $-i k$ ) is identical in (9) and (10), a differentiation can be made from the status marking that uuch combines with. In (9) the dependent status marker $-V k$ prompts an analysis of uuch as a TM-marker, while in (10), the plain status marker -ik motivates an analysis of uúch as an adverbial (see Vapnarsky 1999, p. 142, for Yukatek).

The adverbial uúch can occupy three distinct slots in the clause, clause initially (focused; 10), clause finally (11), and topicalized (12):

$\begin{array}{llll}\text { aw-eer } & \text { mana' } & \text { ch'upraj } & \text { uúch } \\ \text { 2s.A-know } & \text { NEG.EXIST } & \text { woman } & \text { before.EXCL }\end{array}$

'You see, there were no women before' (HB040917_1EChK_12)

$\begin{array}{llllll}a-\text { uúch } & \text { a-teen } & t i & k a ' n-e e n & i c h & \text { naja' } \\ \text { DET-before.EXCL } & \text { DET-1s.IND } & \text { LOC } & \text { live-1s.B } & \text { in } & \text { Naja } \\ \text { 'Before, I used to live in Najá' (HB040915_1GKY_3) } & & \end{array}$

The three functions of uúch, i.e. intransitive verb, TM-marker, and adverbial, correspond to different stages of grammaticalization as outlined in Figure 1:

intransitive verb $\rightarrow$ tense-mood marker $\rightarrow$ free standing adverbial

Fig. 1 - The grammaticalization of uúch.

Aside from differences in grammatical status, as outlined above, there are also differences in semantics and scope with respect to the outlined stages of development. Scope differences between the TM-marker and the adverbial consist of verbal scope for the TM-marker and clausal scope (propositional) for the adverbial. This difference in scope mirrors the one in meaning (see below) where the TM-marker is subjective and the adverbial is intersubjective, an analysis that aligns with Traugott and Dasher's (2002) proposal for the process of intersubjectification with modals (Section 2, above). Differences in scope between forms may be viewed from how they are affected by negation, i.e. the

4. A reviewer noted the apparently contradictory occurrence of aweer (lit. 'you know') in a clause that features uúch as a marker of speaker-exclusive knowledge (below). While the distribution and function of aweer is outside the scope of the present paper, I would like to add that this expression may be compared to the periphrastic expression you see, which a speaker of English could use before going on to explain something (new) to his/her addressee. 
possibility of (semantically) negating a marker as an indicator of scope under, or over negation. Consider Example (13):

$\begin{array}{lcc}m a & \text { inw-eer } & \text { uúch } \\ \text { NEG } & \text { 1s.A-know } & \text { before.EXCL } \\ \text { 'I didn't know (back then).' (UCLAK, cuando murió mi mamá) }\end{array}$

The negated part of the sentence in (13) only concerns the state of 'knowing', not the time when something is/was assumed to be known by the addressee. The TM-marker, however, can be negated, as exemplified in (14):

$\begin{array}{lllll}m a & \text { uúch-ak } & \text { taak-een } & \text { ich } & \text { Palenque } \\ \text { NEG } \quad \text { before-ADV } & \text { leave.DEP-1s.B } & \text { LOC } & \text { PN } \\ \text { 'I went to Palenque not long ago.' (elicited, EChK) } & \end{array}$

In (14), it is the event time that is negated, i.e. 'not long ago', not the event itself. With respect to the semantic development of uúch in Lakandon, this is illustrated in Figure 2:

event description $\rightarrow$ temporal meaning $\rightarrow$ knowledge asymmetry

Fig. 2 - The de-semanticization of uúch.

The change in grammatical status from (full) predicate to adverbial corresponds to an increasing abstraction of meaning, where 'to happen' becomes 'long ago' (TM-marker) and ultimately 'past event (assumed to be) unknown to the addressee' (i.e. 'knowledge asymmetry'; adverbial). ${ }^{5}$ The notion of 'knowledge (a)symmetry' may be attributed to Hanks (1990) who uses it to explore dimensions of meaning in Yukatek demonstratives (Hanks 1990, p. 516). More recently, this notion has been used to analyze evidentials and the less well-known category "engagement" (see Bergqvist 2008, 2012, 2016; Evans 2005; Evans et al. 2017; see Landaburu 2007).

5. A reviewer commented that, from the point of view of Yukatek, the adverbial uúch may be argued to have developed directly from the verbal uúch rather than from the TM-marker. This suggestion is admittedly possible, although there are a couple of arguments for why I advocate the development argued for in the present paper. Firstly, it seems unlikely that a (distant) 'past' meaning would develop twice with two separate functions (i.e. TM-marker and adverbial). Secondly, the increasing degree of abstraction in meaning and grammatical status from lexical, to grammatical with a core function, to discourse level meaning corresponds to what we would expect from the grammaticalization process, as it is currently understood. The time semantics found in the TM-marker are retained in the subsequent development into the adverbial (discourse-like) marker. The fact that all three forms co-exist in contemporary Yucatec cannot be viewed as a counter argument to the proposed analysis in terms of stages of grammaticalization. The present paper shows that the next stage in the grammaticalization cycle has occurred in the disappearance of verbal uúch, which is no longer attested as an independent lexical verb. 
The semantic change found in uúch, i.e. from temporal operator to a marker of knowledge asymmetry, must consider a comparison to the semantically contrastive particles $k a$ 'ch (NL) and kuúch (SL; 'recently', 'a while ago'). kuúch has cognates in all Yukatekan languages, whereas $k a$ 'ch is only found in Yukatek and Northern Lakandon. Kuúch and ka'ch are hypothesized to be two variants with one function in Lakandon; kuuch in the Southern dialect and $k a$ 'ch belonging to the Northern one. McQuown (1967) discusses the meaning of cognate forms in Colonial Yukatek, stating that kachi, "refers to a time earlier today" and kuchi refers to a time "before today" (McQuown 1967, p. 243). In Lakandon, $k u u c h / k a$ 'ch do not encode a temporal separation between the speech event and the narrated event in terms of proximity (see Jakobson 1990 [1957]; Section 5, below), i.e. kuúch/ka'ch cannot be used to answer a when-question about a past event (Bergqvist 2008, p. 260-261). Instead, the speaker's assumption about the addressee's knowledge of a past event constitutes the encoded meaning of the forms. As an illustration, compare (11, repeated here), to (15), both of which refer to past states/events that happened more than 20 years ago.

$$
\begin{array}{llll}
\text { aw-eer } & \text { mana' } & \text { ch'upraj } & \text { uúch } \\
\text { 2s.A-know } & \text { NEG.EXIST } & \text { woman } & \text { before.EXCL }
\end{array}
$$

'You see, there were no women before' (HB040917_1EChK_12)

(15) in-yuúm cheen b'in $u-k a$ ' ich este
1s.A-FB only go 3s.A-do LOC this(sp.) PLN
'Only my uncle was going to go to Chihuahua (as you already know)'6
(HB050328_1KYYM_1)

Example (11) was uttered in the context of telling a story about the history of the Lakandones. In this story there are many instances of uuch, one of these marking a commentary on the shortage of potential wives for Lakandon males in the first half of the 20th century. The events it recounts were probably experienced first-hand by the speaker although this piece of community history is commonly presented as personal knowledge, regardless. The crucial contextual component here is that the person who was told this story (i.e. the author of the present paper) was not expected to know about these historical circumstances.

Example (15), on the other hand, was uttered when the speaker retold a story of his uncle's going to Chihuahua to the author who had failed to get the recorder to capture the story the first time. $k u$ ích $/ \mathrm{ka}$ ' $\mathrm{ch}$ is not restricted to appear in repeated utterances, but is often found with them. From Examples

6. To clarify, the uncle of the speaker did go to Chihuahua in the story, thus ruling out a contrastive reading for kuúch (i.e. Only my uncle was going to go to Chihuahua, but didn't go.). 
(11) and (15), it should be evident that temporality is insufficient to define the semantics of uúch and $\mathrm{ka}^{\prime} \mathrm{ch} / \mathrm{kuu} \mathrm{ch}$.

A salient example of how uuch contrasts with $k a^{\prime} \mathrm{ch}$ in terms of signaling differences in the addressee's knowledge of an event comes from a conversation between Enrique (E; my main consultant) and his aunt Lisa (L). The conversation took place in Lisa's kitchen and was the first time that Enrique and Lisa met in several years, since Lisa lives in Najá and Enrique now lives in Lacanjá, having moved away from Najá almost two decades previous to this encounter. Both speak the northern variety of Lakandon, hence uúch is contrasted to $k a^{\prime} \mathrm{ch}$ in (16):

$$
\begin{aligned}
& \mathrm{E} \text { : uúch-ik } \\
& \text { before.EXCL-ADV.FOC 1s.A-awake-COM 1s.A-mind } \\
& \text { 'I used to be a Christian.' } \\
& \text { b'aje' yaan jum-b'uj k'äb ya'x k'iin tu' in-p'ät-aj } \\
& \text { now.EXCL EXIST one-half hand new year where 1s.A-leave-COM } \\
& \text { 'Now it's five years since I left (the faith)'. } \\
& \mathrm{L}: \text { wa ma'n a-p'ät-ik } \boldsymbol{k a} \text { 'ch-i } \\
& \text { HYP why 2s.A-leave-PLN before.INCL-ADV.FOC } \\
& \text { 'Why did you leave it?' }
\end{aligned}
$$

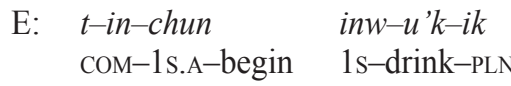

$$
\begin{aligned}
& \text { 'I began to drink.' (HB_050319_1EChK_1) }
\end{aligned}
$$

In the first line, Enrique answers a question posed by Lisa concerning his churchgoing practices, which in this context is equated with the state of Enrique's Christian faith. Enrique uses uúch(ik) in providing Lisa with (new) information regarding his lack thereof and the time since he stopped going to church. Having assimilated this information, Lisa then asks for the reason why Enrique stopped going using $\mathrm{ka}^{\prime} \mathrm{ch}(\mathrm{i} k$ ) to refer to a (stated) event that originates with addressee (Enrique) and which she as addressee, now is informed of. Drinking is frowned upon by the churchgoing crowd, which is why Enrique decided to stop going. He states this reason in the last line.

As already stated, a change from temporal operator to a marker that specifies the speech participant's respective access to knowledge aligns with the notion of intersubjectification, in which the subjective stance of the speaker is extended to include assumptions about the addressee's perspective. A temporal contrast between 'long ago' (uúch) and 'recently' ( $k a$ 'ch/kuúch) has developed into a differentiation between what is assumed to be unknown to the addressee (uich) and known to the addressee $\left(\mathrm{ka}^{\prime} \mathrm{ch} / \mathrm{kuu} \mathrm{ch}\right)$. This development is outlined in Figure 3, below: 
Time and commitment: the grammaticalization of uuch in Lakandon Maya

uúch: temporal distance $\rightarrow$ knowledge asymmetry

kuúch/ka'ch: temporal proximity $\rightarrow$ knowledge symmetry

Fig. 3 - Semantic changes in uúch and kuúch/ka'ch.

Interestingly, the proposed analysis for uúch and $k u$ úch/ka'ch in Lakandon has no synchronic correspondence in Yukatek. According to Vapnarsky (2000), using $-O$ ' together with uuch denotes a distance away from the interlocutors as well as 'shared information' (Fr. savoir partagé; Vapnarsky 2000, p. 202). This semantic analysis is however dependent on the presence of the terminal deictic $-O$ ', which may attach to any deictic form (see Hanks 1990). A past event may be referred to using uúch, but reference to the speech participants' respective knowledge about that event is achieved by attaching one of the available terminal deictics $\left(-a^{\prime},-O^{\prime}\right.$, $-e$, or $-i$ ') to the form. The semantics attributed to these terminal deictics in nontemporal acts of reference, as reported by Hanks (1990), is also appropriate in the analysis of time words in Yukatek (p.c., Vapnarsky 2000, p. 200). In Lakandon, there is no semantic contrast in terms of knowledge (a)symmetry between attaching $-a$ ' or $-O$ ' to uúch. The function of these terminal deictics is to serve as devices for event tracking (see Bergqvist 2008, p. 226) and does not indicate the speaker's expectation with regard to the addressee's knowledge of an event.

Vapnarsky also reports that the semantic value of $k a$ 'ch in Yukatek refers to a state which is no longer true, or which could have been true but did not occur (see Vapnarsky 1999, p. 206-209). While a hypothetical function of $k a$ 'ch is also attested for Lakandon, an otherwise contrastive function cannot be attributed to $k a$ 'ch, nor to uúch, meaning that it is not encoded in either forms. These semantopragmatic differences in cognate forms from two closely related languages serve to illustrate the diversity of semantic change and the nebulous nature of shifters. The synchronic variation found with uuch in Yukatek is perhaps best understood in terms of contextualized token-usage, whereas such conveyed meanings have crystallized in Lakandon to become encoded in forms.

Lastly, we may briefly discuss some of the changes associated with the process of grammaticalization as found with the adverbial uuch. Features to be considered are: frequency of use, obligatoriness, and paradigmaticity.

In Lakandon, uúch is frequently attested in some genres of speech, especially personal narratives. In Yukatek personal narratives, the adverbial uúch occurs with comparably low frequency. A quick comparison between Lakandon and Yukatek reveals that uuch is present in 82 per cent of the lines (73) in one Lakandon narrative, whereas it is found in only 3 per cent of the lines of a Yukatek personal narrative (139; see Bergqvist 2008, p. 331-332). While this comparison admittedly is impressionistic, it aligns well with other observations regarding differences in grammatical status of uuch in the two languages. 
The related issue of obligatoriness is somewhat of a moot point in defining the status of uúch given its function to signal asymmetrical access to knowledge from the perspective of the speaker. This makes the use of this marker pragmatically conditioned and a choice between uuch and a contrasting marker such as ka'ch (e.g. Example 16) is not grammatically required in a way comparable to categorical expressions, such as tense marking in many European languages. The TM-marker uúch, while paradigmatically contrasted to other pre-clitic tense-aspect-mood markers, does not reveal a high degree of obligatoriness either.

The morpho-syntactic properties of uúch as a TM-marker are shared by other aspectual and modal auxiliaries with the same grammatical function, making up a closed paradigmatic set. The adverbial uuch shares morpho-syntactic properties with other particles and free-standing adverbials, most notably $\mathrm{ka}$ ' $\mathrm{ch} /$ kuuch, although these have been less well-charted than the TM-markers in grammatical accounts of Yukatekan languages. Not all auxiliaries that align grammatically with the TM-marker uuch have a comparable free-standing adverbial form, meaning that such developments are not automatic. We may also note here that uúch and $k a^{\prime} c h / k u u ́ c h$ cannot co-occur in the same clause in Lakandon. Such co-occurrence is, however, possible in Yukatek with respect to uúch and $k a$ 'ch. The paradigmaticity of the adverbial uúch and $k a$ 'ch/kuúch is further discussed in Section 6.

Given the observed changes in the grammatical and semantic status of uúch, one may argue that the adverbial uuch has become a form of epistemic marker. In Section 6, I will detail how this development results from the function of both the temporal and the epistemic uuch as related species of "shifters" (Jespersen 1922; see Hanks 2012 for a discussion of evidentials as shifters). Before this discussion, I introduce an analytical model that allows for an account of epistemic marking on the illocutionary level (see Jakobson 1990 [1957], below).

\section{A Jakobsonian model of epistemic marking}

Roman Jakobson's seminal paper "Shifters, verbal categories, and the Russian verb" (Jakobson 1990 [1957]) applies a distinction between the narrated event ("what is said") and the speech event ("the act of saying it") to the analysis of categories of the verb in Russian. Jakobson's proposal was immediately applicable to the analysis of categories like tense and person, establishing an operational model that echoes in modern functional linguistics, even though the model itself is rarely discussed. Jakobson argues for a four-fold separation between the narrated event (En), the speech event (Es), a participant of the narrated event (Pn), and a participant of the speech event (Ps). While this analytical model is used to detail verbal categories in Russian, it is applicable in principle, to comparable categories in any language. 
Using this set of oppositions, Jakobson defined 'tense' as En/Es, i.e. "the narrated event with reference to the speech event" (Jakobson 1990 [1957], p. 46). Implicit to this definition is the character of the relation between the narrated event and the speech event in terms of temporality. 'Aspect' (i.e. perfective/ imperfective), by contrast, only concerns the narrated event and is thus defined as En. According to Jakobson, aspect makes no reference to the speech event, or its participants and is therefore not a shifter like tense.

Mood specifies "the relation between the narrated event and its participants with reference to the participants of the speech event" (ibid.,). Following this definition Jakobson elaborates by adding a formulation attributed to Vinogradov, who says that [mood] reflects the speaker's view of the character of the connection between the action and the actor or the goal" (ibid.,). This composed definition suggests the subjective character of mood, which has since become a key notion in how mood is conceptualized. However, the Russian moods that Jakobson detail are restricted to the conditional, injunctive, indicative, and imperative moods, thereby limiting the general applicability of his definition given our current understanding of notions that may fall under the label of mood in language (see Palmer 2001).

A non-shifter category that specifically concerns the present investigation is 'status', which Jakobson characterizes together with aspect as only concerning the narrated event (En) by defining "the logical quality of the event". Distinct notions of this verbal category are exemplified from Gilyak (see Nivkh, Russia), namely the affirmative, presumptive, negative, interrogative, and negative-interrogative. From the point of view of contemporary conceptions of what would nowadays be called "sentence-type", or "sentence mood", we may question Jakobson's definition of this category. There is a well-attested correspondence between sentence-type and speech-acts (see Austin 1962) in signaling the speaker's communicative intention. This suggests strong reference to the speech situation in the function and meaning of a sentence-type marker. The speech event must therefore be a relevant notion in defining this category as well. One could make the argument that a definition of status (sentence mood/modality) would look quite similar to the one Jakobson proposes for tense, namely a narrated event that refers to the speech event (En/Es), but that this reference does not involve time, but epistemicity and communicative aspects of meaning. Epistemicity in this sense would be possible to connect to Jakobson's characterization of an event in terms of "logical quality"; i.e. if something is asserted as true, or not true, or if an event is presumed to be true. It is, however, not possible to make a formal difference in meaning between temporality and epistemicity in relating the speech event to the narrated event, using Jakobson's terminology and conceptual apparatus alone (i.e. En/Es). 
A possible solution to this analytical limitation is found in Paul Kockelman's (2004, 2010) work on (epistemic) stance in Q'eqchi', a Mayan language spoken in highland Guatemala. Starting from Jakobson's original insights concerning the link between the narrated event and the speech event in verbal categories, Kockelman goes on to pair these with Erving Goffman's formulation of "speaker roles" (Goffman 1981). Goffman proposes a division of the notion of 'speaker' into different roles, namely author (the one who composes the words), animator (the one who speaks the words), and principal (the one who commits to what is being said). A prototypical speaker occupies all three roles, but these may also be separated, perhaps most readily visible in the separation between the author and animator in (direct) reported speech. The utterance John said, "I'll be right over" is uttered by the speaker, who is the animator, but the words of the quoted utterance (I'll be right over) were composed by John (i.e. the author) and not the animator. The separation between speaker-roles in terms of author and animator maps well onto the narrated event and the speech event in Jakobson's terms (see below).

Using Goffman's separation of speaker roles to also include the role of principal, Kockelman (2004) proposes an addition to Jakobson's event types by adding "commitment event" to the two existing event types (i.e. speech event and narrated event). This produces a tripartite division of 'speaker' into the participant roles principal, author, and animator that maps onto the three forms of event types, namely commitment event, speech event, and narrated event. This correspondence is illustrated in Figure 4:

$\begin{array}{lll}\text { Event type } & & \text { Speaker role } \\ \text { Commitment event } & \leftarrow \rightarrow & \text { Principal } \\ \text { Speech event } & \leftarrow \rightarrow & \text { Animator } \\ \text { Narrated event } & \leftarrow \rightarrow & \text { Author }\end{array}$

Fig. 4 - Correspondence between Kockelman's event types and Goffman's speaker roles.

Kockelman's reason for proposing a set of event types that correspond to speaker roles stems from the need to concretize the notion of stance, which although widely used to discuss both modality and evidentiality, is so vaguely defined that it has become useless as an analytical concept (see also Kockelman 2008, for a discussion). The logic underlying Kockleman's model for stance is as follows: if a notion like 'tense' can be accounted for by specifying a relation between the narrated event (the event talked about) and the speech event (the utterance) in terms of temporal separation/ overlap (as Jakobson argues), then epistemic modals may be defined in a similar way by specifying the relation between the speaker's commitment/ 
belief as contained in the commitment event and the utterance found with the speech event. In the default case, the speech event is overlapping with the narrated event, although these can be separated along other dimensions of meaning, such as 'time'.

In discussing Q'eqchi' epistemic modals, Kockelman argues that the commitment event is identical to the speech event when an assertive utterance is epistemically unmarked. In terms of speaker roles, this is equal to saying that the one who says something (animator) is also the one who is committed to what s/he says (principal). The 'factual' modal marker pe' in Q'eqchi', is the modal closest to this default case.

Q'eqchi'

$\begin{array}{llll}\text { (17) } x \text {-Ø-hulak } & \text { pe' chaq ewer } \\ \text { PFV-3.SetA-arrive } & \text { FACT } & \text { hither yesterday }\end{array}$

'He did arrive yesterday.' (addressee-focused) or 'He arrived yesterday!' (speaker focused; Kockelman 2004, p. 140 [my adjusted glossing]) ${ }^{7}$

The epistemic modal markers discussed by Kockelman along with their encoded semantics are listed in Table 1:

\begin{tabular}{|l|l|l|}
\hline$\varnothing$ & \multicolumn{1}{|c|}{ Gloss } & \multicolumn{1}{c|}{ Meaning } \\
\hline$p e^{\prime}$ & Fnmarked & $\begin{array}{l}\text { In a non-specified world, speaker is committed } \\
\text { to the truth of } p\end{array}$ \\
\hline tana & Afactive & $\begin{array}{l}\text { In this world, speaker is committed to the truth } \\
\text { of } p\end{array}$ \\
\hline taxaq & Optative & $\begin{array}{l}\text { In a wish world, speaker is committed } \\
\text { to the truth of } p\end{array}$ \\
\hline raj & Counterfactive & $\begin{array}{l}\text { In another world, speaker is committed } \\
\text { to the truth of } p\end{array}$ \\
\hline moko...ta & Nonfactive & $\begin{array}{l}\text { In a non-specified world, speaker is committed } \\
\text { to the truth of not } p\end{array}$ \\
\hline
\end{tabular}

Table 1 - Semantic meaning of modal clitics in Q'eqchi'

(after Kockelman 2004).

7. From the point of view of language use, the instantiation of pe' implies either an opposing stance (e.g. negated) by another person (e.g. the addressee) or a previous, contradictory stance assumed by the speaker. As this paper argues, there are forms that encode a stance about other another stance (i.e. secondary stances), namely uúch and $k a^{\prime} c h / k u u ́ c h$ (see Section 6, below). 
Kockelman's analysis of Q'eqchi' modals emphasizes their different scope properties. Kockelman draws attention to distributional and grammatical properties of these and arranges them along a cline where the 'factual' $p e$ ' has the widest scope and the 'non-factive' moko...ta has the narrowest scope. However, the definition of meaning inherent to the modal forms in Q'uqchi' is separate from the scope properties of the forms. Scope correlates with semantics, but can only be defined against the grammatical status and syntagmatic positioning of a form with respect to the predicate and/or the propositional content of the utterance.

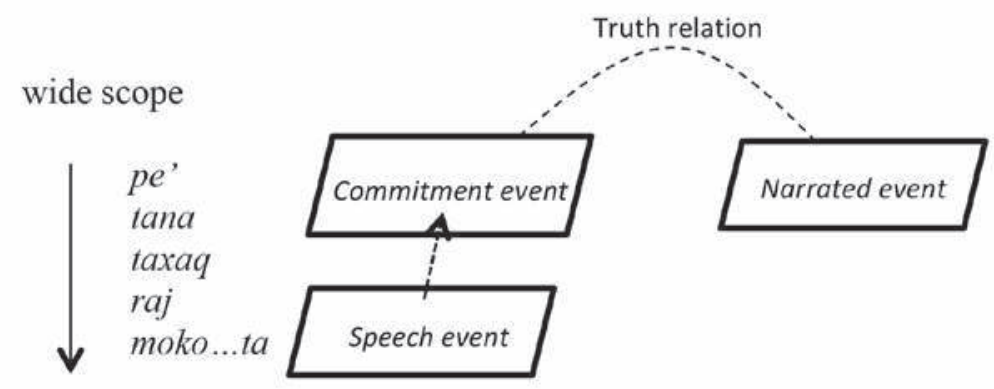

narrow scope

Fig. 5 - Scope properties of Q'eqchi' modals in terms of event relations (after Kockelman 2010, p. 125).

The scope properties of Q'eqchi' modals warrants a separation into two groups where pe', tana, and taxaq form one group and raj and moko...ta form a second group. The latter two forms have scope over core operators, such as tense and aspect, as well as focus constructions, but not over the illocutionary force of the utterance, corresponding to sentence-type. The first group, featuring pe', tana, and taxaq are more ambiguous when it comes to scope over the illocution, but otherwise share scope properties with raj and moko...ta. The common properties of the forms constitute an argument for viewing the group of markers as a paradigmatic set. What supports making a separation between forms in terms of scope, is that e.g. pe' can have scope over any of the other forms, whereas the reverse is not possible.

An important aspect of Kockelman's proposal is that a difference in the scope properties of epistemic modals (at least in Q'eqchi') may be translated into “degrees of separation" between the commitment event and the speech event. This separation becomes visible from the scope properties of the forms, i.e. the wide scope pe' may be conceptualized in terms of an almost complete overlap between the speech and commitment event, whereas the form with the narrowest scope, moko...ta, signals a greater degree of separation between the two event-types. Kockelman's 
analysis proposes that the speaker's commitment is entailed in all modal forms, but that this commitment is relevant to different worlds, thus somewhat bridging the gap to traditional analyses of modals as operators signaling possible worlds where events can take place. Cross-linguistically, Kockelman's analysis aligns with functional accounts of evidentials (e.g. Hengeveld and Dall'Aglio Hattnher 2015) as well as individual descriptions of evidential systems (e.g. Faller 2002), where some evidential forms act on the propositional level (i.e. belonging to the narrated event in Jakobson's terms) while others are analyzed as illocutionary modifiers (i.e. acting on Jakobson's speech event).

\section{Application of Kockelman's model to the analysis of uúch}

Before we apply Kockelman's model to the analysis of uúch and $k a$ 'ch/kuúch, some comments on his proposal are in order. Firstly, Kockelman's proposal ameliorates problems that (from our current understanding of grammar) allows us to differentiate between categories like tense (En/Es) and (epistemic) modality which requires the inclusion of a subjective component that is difficult to represent using Jakobson's four-way distinction into events and participants, although exchanging Es (speech event) for Ps (participant of speech event), to yield the formula En/Ps, goes some way to signal this aspect of meaning. By drawing on Goffman's insights on speaker roles, Kockelman makes visible the gradual commitment of the speaker in qualifying a proposition as perceived, inferred, probable, or possible; notions that belong to the domain of epistemology as expressed by modal and evidential forms.

Another aspect of Kockelman's model may be inferred, namely that the commitment event is necessarily present in modeling any operator, or sets of operators that involves reference to a speech event. This follows from the fact that a speech event necessarily involves a speaker, and that the speaker roles of author, animator, and principal underlie any utterance made by a speaker. So, even if a category like tense may not encode a distinction between saying something and committing to something, it must be assumed to be available simply from the existing reference to the speech event.

With a starting point in these observations, we may postulate that the configuration of event-types relevant to the analysis of uuch, is similar to the one Kockelman uses to account for Q'eqchi' modals. This follows from the function of uúch as an epistemic marker and an assumed element of speakercommitment in uúch alongside its 'past' temporal meaning. Issues that need to be addressed in this regard are scope differences between uúch and kuúch/ $k a$ 'ch and the paradigmatic status of this set of forms.

Starting with the issue of paradigmaticity, uúch and kuúch/ka'ch contrast by signaling different knowledge (a)symmetries, vis-à-vis the speech participants. However, they display differences in grammatical status, as well as in their 
semantics. Mostly, these differences may be attributed to the histories of the two markers as outlined in Section 4. As stated there, the grammaticalization of uuch is from an intransitive (one-place) predicate to an adverbial, via the function of an auxiliary TM-marker. This development is not shared by kuúch and $k a^{\prime} c h$, which are adverbial both diachronically and synchronically. This difference is clearly visible in the retained function of uuch to specify a point in time, thus making it available to answer a "when-question", a function that kuúch/ka'ch does not have (Bergqvist 2008, p. 261). Predictably, kuúch/ka'ch does not function as TM-markers although they of course can be fronted in a focused position (see Example 10, for uúch, above).

The question of differences in scope between uúch and kuúch/ka'ch may be approached from a grammatical and semantic point of view. Scope is generally regarded as a semantic phenomenon that correlates with the grammatical status of a marker. An example of this relationship can be seen in the relative placement of evidential, modal, and tense markers in languages that have these categories in their grammar (see Bybee 1985). The placement of evidentials outside of epistemic modals, which in turn are placed outside tense markers (all with respect to the verbal core), correlates with how instances of one category may affect (or remain unaffected by) a member of another category. In the case of uúch and kuúch/ka' ch, it is not possible to morpho-syntactically differentiate the two given their identical grammatical status. Furthermore, it is not possible to differentiate between uúch and $\mathrm{kuu}$ ch/ka'ch from their relative placement in a clause since they cannot co-occur. However, if one takes into account the semantic content of the forms, one may argue that uuch is more like a temporal operator than kuuch/ka'ch, which only has epistemic and discourse meaning without encoding temporal information. In a paradigmatic sense, however, the temporal feature of pastness must be considered inseparable from the meaning of the latter forms. This function as temporal operator suggests the partly propositional status of uuch, a feature that appears absent in kuuch/ka'ch, which is entirely discourse-like.

If we return to the question of how Kockelman's proposal can be used to represent the function and meaning inherent to the investigated forms, we may start with the observation that the commitment event (Ec) and speech event (Es) overlap in both forms. Both uúch and kuúch/ka'ch entail the speaker's commitment to what is being said. The difference between the forms consists of whether this commitment is shared with the addressee, or not, and does not involve "degree of commitment". Modal notions are commonly expressed by TM-markers such as je' ('assurative'), or taák ('desiderative') in Lakandon, as well as in Yukatek. These may co-occur with the adverbial uúch, which predictably has scope over aspectual-modal operators.

There is a separation between the speech event (Es) and the narrated event (En) in terms of temporality given that propositions marked by uúch and kuúch/ 
$k a$ 'ch are necessarily 'past'. This temporal separation is underspecified with regard to temporal distance, however. We may illustrate the event configuration applicable to uúch and $k u u c h / k a$ 'ch as epistemic markers in the following way:

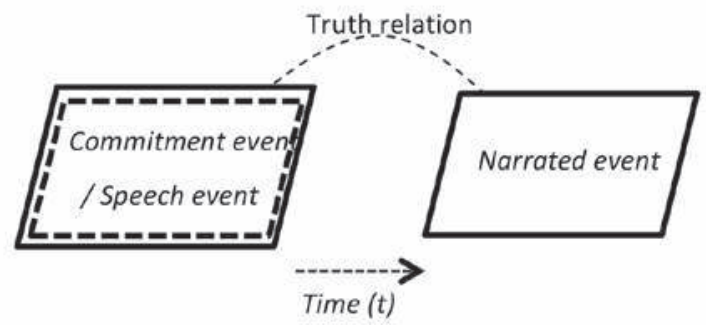

Fig. 6 - Event configuration in uúch and kuúch/ka'ch.

In order to make the semantic distinction between uúch and $k u u c h / k a$ 'ch visible in terms of a configuration of event types, Figure 6 needs to be modified to allow for a representation of the difference between shared and non-shared commitment.

\section{uúch and $k a^{\prime} c h / k u u ́ c h$ as operators of second-order stance}

How do we then, conceptualize the proposed features of uúch and $\mathrm{ka}$ 'ch/kuúch in terms of event configuration? This requires that we introduce the notion of "second-order stance", or "stance about stance", as briefly discussed by Kockelman. A secondary stance may concern the speaker's stance towards his/her own previous stance, but may also include other forms of meta-stance (Kockelman 2004, p. 143-144). A first-order stance is conceived by Kockelman as consisting of a relation between the commitment event and the speech event in e.g. modals, (e.g. She could have arrived), or between the commitment event and the narrated event in complement-taking predicates (e.g. I think (that) she has arrived; see Kockelman 2004, p. 131-133). Achieving a secondary stance, where one stance is embedded in another, is a process that Kockelman leaves largely unspecified. In the context of the present discussion, how could such an embedding be represented?

Without drawing on the notion of stance (for obvious reasons), Jakobson analyses "reported evidentials" as "narrated speech events", i.e. a speech event contained within a narrated event (EnEns/Es; see Jakobson 1990 [1957], p. 392). If stance is conceptualized as a relation between the commitment event and the speech/narrated event, then the embedding of a speech event in a narrated event, which in turn is related to a speech event, may be one example of a secondary stance. Admittedly, the notion of commitment event is not part of Jakobson's proposal, but as suggested in Section 6, the commitment event may be regarded 
as underlyingly present as a consequence of the presence of a speech event and the defining role of a speaker in that event type (see Section 6, above).

Following Kockelman's model for representing relations between event types, the separation between exclusive and shared knowledge in uuch and $\mathrm{ka}$ 'ch/kuúch can be analyzed as one commitment event embedded in another. This is seen in Figure 7:

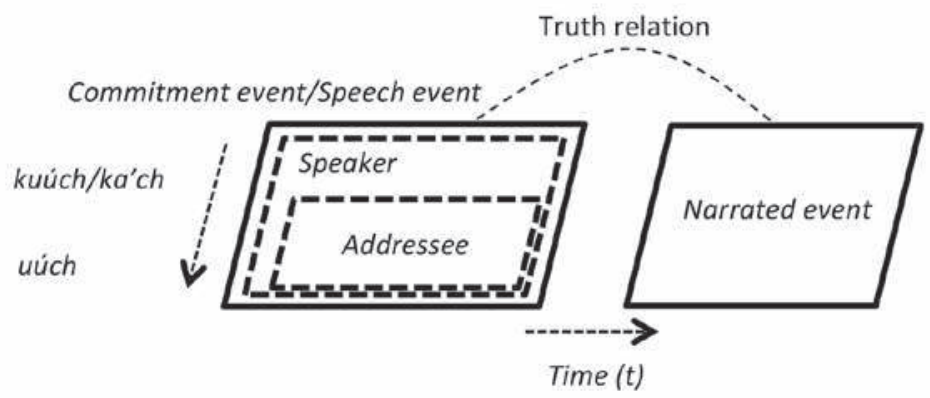

Fig. 7 - Embedded commitment events as second-order stance: uúch and kuúch/ka'ch.

Why should the (assumed) commitment of the addressee be embedded? The phrase "in the mind of the speaker" serves to illustrate this conceptualization. It is the speaker's assumption that is at stake, not the expressed commitment of the addressee. The speaker's assumption in this regard may be well founded or poorly supported; a distinction of this kind cannot be found in the investigated forms. From the point of view of speaker role, one may observe that the speaker inhabits all three roles (author, animator, principal), while sharing only that of the principal with the addressee. This must be viewed as the dominance of the speaker's point of view in uuch and $k a$ 'ch/kuúch, a proposal that aligns with Traugott and Dasher's idea that intersubjectivity is preceded by, and indeed requires subjectivity. ${ }^{8}$

8. This relation between subjectivity and intersubjectivity applies to the grammaticalization process discussed here, namely the intersubjectification of forms that originally encode the subjective point-of-view of the speaker (e.g. modals and pronouns). It is by no means a statement that applies to the ongoing debate concerning the relation between subjectivity and intersubjectivity in an ontological sense. However, a brief comment in this regard is that what sometimes is called "primary intersubjectivity" (see Trevarthen 1979) as a pre-linguistic, cognitive predisposition that makes language acquisition possible, allows for the development of the subject's awareness of him/herself as a subject. Secondary intersubjectivity, which concerns the acknowledgement and manipulation of points-of-view (i.e. Machiavellian skills) develops later and could arguably be viewed as a consequence of the subject's increasing awareness of him/herself as a subject among other subjects that are assumed to share the primary subject's desires and perceptions. 
An alternative to an embedding of commitments, i.e. analyzing the addressee's commitment as a commitment independent of the speaker's own, is difficult to maintain given that the addressee's expressed commitment may turn out to differ from the speaker's assumption, where the speaker's own commitment is entailed. The intersubjective meaning component in uúch and $\mathrm{ka}$ 'ch/kuúch is encoded and on the same level semantically and thus non-defeasible. If we compare Traugott and Dasher's proposal to that of Kockelman, we may regard the process of intersubjectification as the development of second-order stances from first-order ones.

How is this development possible? If we consider the defining feature of a shifter to be the necessary reference to the speech event, then this component may allow for reference to any available dimensions of meaning that may be connected to speaker-roles as reflected in the event configuration proposed by Kockelman. A prediction is that categorical expressions that only refer to the narrated event are not available for developing second-order stance functions without first developing reference to the speech event. Hence, a 'perfective' aspect marker (which only refers to the narrated event) may develop into a shifter that makes reference to the time of the speech event or the (modal) attitude of the speaker, and only then develop into a marker of intersubjectivity. While I have come across no accounts that would contradict this prediction, it remains to be confirmed, subject to empirical testing.

\section{Summary}

The grammaticalization of uúch may be viewed as an instance of intersubjectification, which makes reference to a past event, but also expresses the speaker's assumption that the event referred to is unknown to the addressee. The parallel development of kuúch/ka'ch to signal a contrasting stance, namely that the speaker refers to a past event that is assumed to be known to the addressee, has produced a paradigmatic set of forms in Lakandon grammar. The notion of 'knowledge (a)symmetry' is used to account for this semantic contrast. Differences in the scope properties of the TA marker and the adverbial uuch align with their different grammatical statuses, where the TA marker has verbal scope and the adverbial has clausal scope.

The second part of the paper proposes that uúch and $k a$ 'ch/kuúch can be analyzed as markers of second-order stance (see Kockelman 2004). This form of stance may be conceptualized as an embedding of the addressee's commitment in the (primary) commitment of the speaker. Additionally, there is a temporal meaning component ('past') that is analyzable as a separation between the speech event (Es) and the narrated event (En), following Jakobson's original formulation of event types. This mode of analysis allows for a comparison 
of uúch and $\mathrm{ka}$ 'ch/kuúch to other forms of epistemic marking on comparable grounds; shedding some light on the notion of intersubjective stances.*

* Manuscrit reçu en mars 2015, accepté pour publication en octobre 2015.

This article is part of the Special issue Measures and textures of time among the Maya: the said, the written, and the lived.

\section{Glossing abbreviations}

1: first person, 2: second person, 3: third person, A: ergative marker, ADV. FOC: adverb focus (suffix), AF: agent focus, B: absolutive marker, CAUs: causative, CL: classifier, COM: completive aspect, CP: completive status, CPASS: canonical passive, DEP: dependent status, DET: determiner, DIST: distal deictic, DUB: dubitative, ENC: enclitic, EP: epenthetic segment, EXCL: exclusive, EXIST: existential, FACT: factual, FUT1: event dependent future, FUT2: indefinite future, IMP: imperative, INC: incompletive aspect, INCL: inclusive, IND: independent form, ITV: intransitive thematic vowel, IV: intransitive, LOC: locative, NEG1: negative (dependent), NEG2: negative (plain), NMZR: nominalizer, NOM: nominal, OPT: optative, OST: ostensive, PEN: penative aspect, PL: plural, PLN: plain status, PLN.IV: plain status intransitive, PN: proper noun, POSS: possessive, PREP: preposition, REFL: reflexive, s: singular, SSDTVCOM: status suffix for derived transitive verb in the completive, SUB: subordinate, TERM: terminative, TR: transitive, TRZ: transitivizer. The code after the examples corresponds to the recording identification (e.g. HB041025_ChN_1: name of person recording date of recording abbreviation for the speaker's name number of recording, in case of several recordings on the same date).

\section{References cited}

Aksu-Koç Ayhan A. and Dan I. SLOBIN

1986 "A Psychological Account of the Development and Use of Evidentials in Turkish", in Wallace Chafe and Johanna Nichols (eds.), Evidentiality: the Linguistic Coding of Epistemology, Ablex, Norwood (New Jersey), p. 159-167.

Austin John L.

1962 How to do Things with Words: The William James Lectures delivered at Harvard University in 1955, J. O. Urmson and Marina Sbisà (eds.), Clarendon Press, Oxford.

BERgQvist Henrik

2006 "Semantics of temporal deictics in Lakandon Maya", in Proceedings of the Conference on Indigenous Languages of Latin America II [on-line], University 
Time and commitment: the grammaticalization of uúch in Lakandon Maya

of Texas at Austin 27th-29th October 2005, http:/www.ailla.utexas.org/site/ cilla2_toc.html

2008 Temporal Reference in Lakandon Maya: Speaker-and Event Perspectives, Ph.D., School of Oriental and African Studies, University of London. London.

2012 "Epistemic marking in Ika (Arwako)", Studies in Language (News from the field), 36 (1), p. 151-178.

2016 "Complex Epistemic Perspective in Kogi (Arwako)", International Journal of American Linguistics, 82 (1), p. 1-34.

Bricker Victoria, Eleuterio Рoоt YAH and Ofelia Dzul de Poot

1998 A Dictionary of the Maya Language As Spoken in Hocabá, Yucatán, The University of Utah Press, Salt Lake City.

Bybee Joan L.

1985 Morphology: A Study of the Relation between Meaning and Form, Typological Studies in Language, 9, John Benjamins, Amsterdam.

Bybee Joan, Revere Perkins and William Pagliuca

1994 The Evolution of Grammar: Tense, Aspect, and Modality in the Languages of the World, University of Chicago Press, Chicago.

CAMPBell Lyle

2001 “What's wrong with grammaticalization?”, Language Sciences, 23 (2-3), p. 113-161.

Cinque Guglielmo

1999 Adverbs and Functional Heads: A Cross-Linguistic Perspective, Oxford University Press, Cary (NC, USA).

DANZIGER Eve

1996 "Split transitivity and Active-Inactive Patterning in Mopan Maya", International Journal of American Linguistics, 62, p. 379-414.

ENGLAND Nora and Stephen ELLIOT

1990 Lecturas sobre la Lingüistica Maya, Plumsock Mesoamerican Studies, South Woodstock (Vermont).

Evans Nicholas

2005 "View with a view: towards a typology of multiple perspective", Berkeley Linguistics Society, p. 93-120.

Evans Nicholas, Henrik BergQvist and Lila SAn RoQue

2017 "The grammar of engagement I: framework and initial exemplification", Language and Cognition, p. 1-31.

FALLER Martina

2002 Semantics and Pragmatics of Evidentials in Cuzco Quechua, Ph.D., Stanford University.

Foley William A. and Robert D. VAn Valin, Jr.

1984 Functional syntax and universal grammar, Cambridge University Press, Cambridge (England).

GoFFMAN Erving

1981 Forms of Talk, University of Pennsylvania Press, Philadelphia. 
HANKS William F.

1990 Referential practice: Language and lived space among the Maya, University of Chicago Press, Chicago.

2009 "Fieldwork on Deixis", Journal of Pragmatics, 41 (1), p. 10-24.

2012 "Evidentiality in social interaction", Pragmatics and Society, 3 (2), p. 169-180.

Heine Bernard

2008 "Grammaticalization", in Brian D. Joseph and Richard D. Janda (eds.), The Handbook of Historical Linguistics, Blackwell Publishing, Oxford, part. VI (18).

Hengeveld Kees and Marize Mattos Dall'Aglio Hattnher

2015 "Four types of evidentiality in the native languages of Brazil", Linguistics, 53 (3), p. 479-524.

HimmeLmann Nikolaus

1998 "Documentary and descriptive linguistics", Linguistics, 36, p. 161-195.

Hofling Charles Andrew

2000 Itzaj Maya Grammar, University of Utah Press, Salt Lake City.

JAKOBSON Roman

1990 [1957] "Shifters and verbal categories", in Linda R. Waugh and Monique Monville-Burston (eds.), On language, Harvard University Press, Cambridge (MA), p. 386-392.

JESPERSEN Otto

1922 Language; its nature, development, and origin, George Allen and Unwin Ltd., London.

KAUFMAN Terrence

1990 "Algunos Rasgos Estructurales de los Idiomas Mayances con Referencia Especial al K'iche'", in Nora C. England and Stephen R. Elliot (eds.), Lecturas sobre la Lingüística Maya, Plumsock Mesoamerican Studies, South Woodstock (Vermont), p. 59-116.

1991 "Notes on the Structure of Yukateko and other Yukatekan languages (NovDec 1991)", ms, p. 106-210.

Kockelman Paul

2004 "Stance and Subjectivity", Journal of Linguistic Anthropology, 14, p. 127-150.

2010 Language, Culture, and Mind: Natural Constructions and Social Kinds, Cambridge University Press, Cambridge.

LANDABURU Jon

2007 "La modalisation du savoir en langue Andoke (Amazonie Colombienne)", in Zaltka Guentchéva and Jon Landaburu (eds.), L'énonciation médiatisée II. Le traitment épistémologique de l'information: illustrations amérindiennes et caucasiennes, Éditions Peeters, Paris, p. 23-47.

Levinson Stephen C.

2000 Presumptive Meanings: The Theory of Generalized Conversational Implicature, MIT Press.

McQuown Norman A.

1967 "Classical Yucatec (Maya)", in Norman A. McQuown (ed.), Handbook of Middle American Indians, Supplement 5, p. 201-247. 
Time and commitment: the grammaticalization of uuch in Lakandon Maya

PALMer F. R.

2001 Mood and Modality, Cambridge University Press, Cambridge [2 $2^{\text {nd }}$ ed.].

Traugott Elisabeth Closs and Richard B. DASHER

2002 Regularity in Semantic Change, Cambridge University Press, Cambridge.

Trevarthen Colwyn B.

1979 "Communication and cooperation in early infancy: A description of primary intersubjectivity", in Margaret Bullowa (ed.), Before Speech, Cambridge University Press, Cambridge.

UlRich Matthew and Rosemary ULRICH

1971 "Mopan Maya", in Mary Shaw (ed.), According to our ancestors: Folk texts from Guatemala and Honduras, Summer Institute of Linguistics of the University of Oklahoma (Publications in linguistics and related fields, 32), p. 167-192, 411-430.

VAPNARSKY Valentina

1999 Expressions et conceptions de la temporalité chez les Mayas Yucatèques (Mexique), thèse de doctorat en ethnologie, Université de Paris 10, Nanterre. 
